\title{
Proposed Tasks of Enceladus Missions' Instrumentation in the Context of Their Astrobiological Coals
}

\author{
Katarzyna Kubiak, Jan Kotlarz \\ Łukasiewicz Research Network - Institute of Aviation, Al. Krakowska 110/114, Warsaw, 02-256, Poland \\ Natalia Zalewska \\ Space Research Centre of the Polish Academy of Sciences, Bartycka 18A, Warsaw, 00-716, Poland \\ Urszula Zielenkiewicz \\ Institute of Biochemistry and Biophysics of the Polish Academy of Sciences, Pawińskiego 5a, Warsaw, 02-106, Poland
}

\begin{abstract}
Enceladus, Saturnian satellite, is a very significant object for astrobiologists due to the presence of liquid water that forms the ice-covered ocean. Water ice geysers escape from the south pole region through cracks in the ice shield. During the Cassini flight, the probe took samples of plumes matter recognizing besides other methane and molecular hydrogen. Since then, hypotheses have been formulated that life forms similar to those found in the Lost City Hydrothermal Field in the Atlantic ocean bottom may occur near Enceladus' hydrothermal chimneys. In our work, we analyzed the possibility of a microbial factor detection in the Enceladus geysers. We used as model organisms selected extremophiles. We investigated multi-spectral cameras and mass spectrometers intended for use in mission proposals to Enceladus: Enceladus Orbiter, Enceladus Life Finder, The Explorer of Enceladus and Titan and THEO mission. The review pointed that the configuration of mass spectrometers and the proposed parameters of scientific orbits are appropriate for detecting volatile organic compounds corresponding to selected microorganisms such as aldehyde, ethanol, benzene, toluene, indole, or violacein. The possible presence of a microbiological component with physical dimensions in the order of several micrometres can only be observed for areas of geyser formation at their higher density (>10 ppm) and with the occurrence of the "snowing microbes" phenomenon. We have found that particularly useful optical channels are 780-975nm, 860-910 nm, and 5.0-5.3 $\mu \mathrm{m}$.
\end{abstract}

\section{Introduction}

Enceladus is a particularly attractive Saturnian satellite where life can survive because of liquid water and energy availability [1]. Life finding mission concepts (i.e. Enceladus Orbiter, Enceladus Life Finder, The Explorer of Enceladus and Titan, Testing the Habitability of Enceladus's Ocean) were proposed, analyzed, and discussed in recent years. Mission designs were focused on direct life detection (i.e. microbial collection during

Autor korespondujący:

Jan Kotlarz, Jan.Kotlarz@ilot.lukasiewicz.gov.pl

Artykuł recenzowany

nadesłany 22.10.2020 r., przyjęty do druku 29.12.2020 r. passage through plume) or indirect, i.e. measuring relative concentrations of amino acids, amino acid excess, lipid molecular patterns, or lipid distributions. A different area of interest is the environmental parameters of the ocean. Interestingly, such a small astronomical object with a diameter of less than $500 \mathrm{~km}$ is thermally active [2].

The origin of the material is emerging into space by the "Tiger Stripes" linear depressions in the southern region. Closer measurements of Cassini's mission pointed out that these structures are surprisingly analogous to the oceanic ridges on Earth. In addition to the unique "stepped" composition, something like spreading and transformation damage was observed. It is speculated that Enceladus' "rifting" is associated with the existence of chimneys, as is the case with Earth gaps. The ejected substance of Enceladus plumes forms something like curtains. The flows seem to be continuous and produce a large haze of fine ice dust around the moon, which supplies material to one of Saturn's rings, the E-ring (fig. 1) [3].

"Tiger stripes" consist of 5 gaps spaced about $35 \mathrm{~km}$ apart, and the ice crust under them is only $5 \mathrm{~km}$. Scientists sug- 


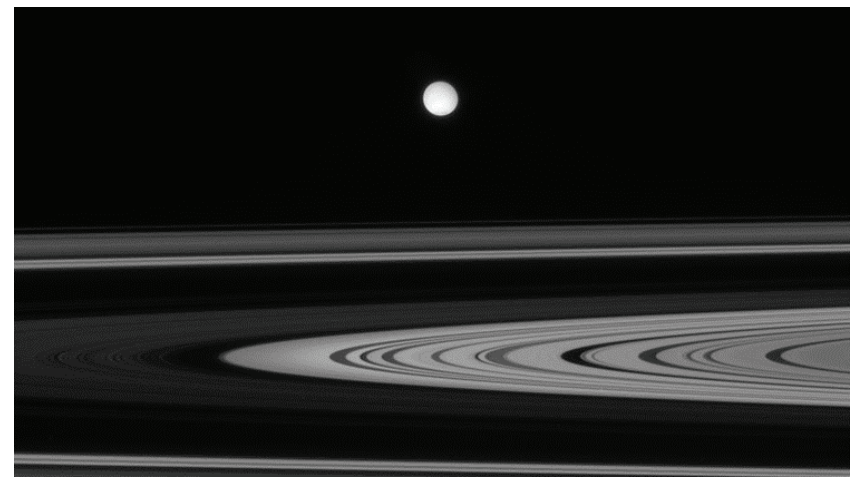

Fig. 1. Enceladus and Saturnian rings, NASA's Cassini probe image in $640 \mathrm{~nm}$ optical channel [NASA/JPL/University of Arizona]

Rys. 1. Enceladus i pierścienie Saturna, zobrazowanie sondy Cassini w kanale $640 \mathrm{~nm}$ [NASA/JPL/University of Arizona]

gest that the brackish ocean of Enceladus $\left(-\mathrm{Na},-\mathrm{Cl},-\mathrm{CO}_{3}\right)$ has an alkaline $\mathrm{pH}$ from 11 to 12 [4]. This allows us to make important conclusions such as a high pH may be a consequence of the serpentinization of olivine [5]. As a result of serpentinization, such products are created, among others as $\mathrm{H}_{2}$ and $\mathrm{CH}_{4}$ which are considered as potential places where life could thrive. Possible similarities of conditions between Enceladus ocean bottom and the carbonate mineral matrix of actively venting chimneys of the Lost City Field (LCHF) located $15 \mathrm{~km}$ west of the Mid-Atlantic Ridge [6] allow microbial life investigation and development a kinetic model of microbial ascent process through the ice shield to the outer space.

Research done in the middle of the 2000s at Washington University gave us knowledge about the biodiversity of the LCHF environment. The porous interior walls of the most actively venting chimney are inhabited by archaeal biofilm dominated in 80-90\% by a single phylotype of Methanosarcinales (Lost City Methanosarcinales [LCMS]) [7]. The biofilms contain $2 \times 10^{6}$ and $3.1 \times 10^{8}$ cells $/ \mathrm{mL}$ in regions awash in hydrothermal fluids.

Abundant Lost City Methanosarcinales have adapted to the temperature $\sim 90{ }^{\circ} \mathrm{C}, \mathrm{pH} 9-11$, and vent fluids with dissolved hydrogen $\left(\mathrm{H}_{2}\right)$ and methane $\left(\mathrm{CH}_{4}\right)$. Also, a 16Sr RNA gene sequence analysis showed strains belonging to Thermococcales and uncultured Crenarchaeota identified in vent fluids. In the oldest chimneys (lower temperature, less venting) pores were dominated by a single group of anaerobic methanotrophic archaea [8]. Rare sequences in young chimneys were commonly more abundant than in older chimneys. A small number of species also dominate the bacterial communities, mostly methylotrophic genera $[8,9]$.

In addition to the microorganisms classified in LCHF, extremophiles whose at least some of the features contribute to survival in the environment characteristic of the Enceladus ocean floor - high salinity, varied temperature or probable sources of X-rays (Saturn rings or probably hydrothermal chimneys themselves) - should be taken into account. These are microorganisms containing very characteristic pigments such as carotenoids, tyrosine, or indole. These microorganisms are diverse in terms of physical parameters. A set of their spectral signatures was collected as part of the "Virtual Planetary Laboratory Biological Pigments database" [10].

In situ instruments like a dust analyzer successfully sampled the plume particles on November 2, 2009, during the $100 \mathrm{~km}$ pass through the plume resulting mass production rate $\sim 2.5 \mathrm{~kg} / \mathrm{s}$. An analysis of dust analyzer data obtained during the closer, $50 \mathrm{~km}$ altitude, flyby on October 28, 2015, registered higher particle densities and a mass production rate of $\sim 5 \mathrm{~kg} / \mathrm{s}$, consistent with the earlier results. None of the biosignatures were registered during all passes via plume.
Porco et al. estimations proved that for 1-3 $\mu \mathrm{m}$ dimension cells (LCHF analog) an average number of the microbial component particle collection during close $50 \mathrm{~km}$ altitude pass is $\sim 1$ assuming Cassini instrumentation parameters. Also, ParticleIn-Cell kinetic simulations for $10 \mathrm{~km}$ deep ocean and $1 \mu \mathrm{m}$ cell sizes suggested the number of the microbial component particles during the flight with in-situ sampling $\sim 1$ particle per single plume pass [6]. Those results imply that for the altitudes 50-100 km in-situ sampling methods maybe not proper for microorganisms their self and it can be assumed that to detect biosignatures, it is necessary to use techniques based on the multispectral analysis, i.e. multispectral images of the plumes, surface near plume sources ("snowing microbes" phenomenon) and of the whole surface between "TigerStripes". Cassini's Medium Angle Camera (MAC) proved successful in plumes, E-ring, and surface image acquisition.

The crucial factor for the effective detection of the microbial component is the spectral signature that distinguishes it from the abiotic elements of the plume and the surface. Plume's main component is water in two states: solid and vapor. Also, the other organic and biologically significant compounds were detected during previous missions. Cassini during its closest approach to Enceladus' surface in July 2005 collected data using the Ion and Neutral Mass Spectrometer. The best estimation of the composition gives us: $91( \pm 3) \% \mathrm{H}_{2} \mathrm{O}, 3.2( \pm 0.6) \% \mathrm{CO}_{2}$, $4.0( \pm 1.0) \% \mathrm{~N}_{2} / \mathrm{CO}$ and $1.6( \pm 0.4) \% \mathrm{CH}_{4} . \mathrm{H}_{2}$ was also discovered in the plume's vapor.

In our study, we collected the parameters of sample microorganisms (reflectance, mass spectral signatures) and the parameters of the proposed instruments in Enceladus research probes (multispectral cameras, mass spectrometers) and analysed the possibility of detection of the potential biological component.

\section{Materials and methodology}

\subsection{Choice of organisms}

To select terrestrial microorganisms that can be used as analogues of the biological component of the ocean bottom of Enceladus, a review of typical pigments and their role for microorganisms was performed. Due to the unavailability of sunlight on the ocean floor, typical photosynthesis pigments: chlorophyll-a and chlorophyll-b, as well as pigments absorbing and reflecting light for metabolism or protection, have been omitted. We assumed that useful types of Enceladus ocean bottom environment pigments are:

- some rhodopsins (function: phototropism),

- carotenoids(antioxidants),

- tyrosine derivative (temperature extremes protection),

- siderophore (acquisition of iron),

- prodignine (growth regulation),

- indole derivative (protection against competition and grazing) and

- luciferin (bioluminescence).

Below are some typical examples of microorganisms that produce the above types of selected pigments.

Halobacterium salinarum. An extremely halophilic marine obligate aerobic archaeon produces bacteriorhodopsin (pigment type: rhodopsin). As other halophilic archaea species, this archaeon utilises compatible solutes (in particular potassium chloride) to reduce the osmotic stress to survive in the extremely salty environments. This bacteria also produces the carotenoid bacterioruberin [11].

Deinococcus radiodurans. A species of extremophilic bacterium that is the most resistant to ionizing radiation organism 
known to science. D. radiodurans can endure extreme conditions that would kill most lifeforms. Organisms of this species experience high temperatures and exposure to poisons. They are also resistant to oxidative stress. $D$. radiodurans contains the carotenoid deinoxanthin [12].

Cryptococcus neoformans. This species is an opportunistic fungal pathogen and produces black melanin-like pigments. Melatonin production is associated with virulence and increases resistance to environmental damage as well [13, 14].

Pseudomonas putida. Saprotrophic soil bacterium. It demonstrates a very diverse metabolism, including the ability to degrade organic solvents such as toluene, which was discovered as a component of Enceladus geyser plumes. It produces pyoverdine (pigment type: siderophore), which allows the absorption of iron [15].

Serratia marcescens. The opportunistic pathogen produces the red pigment - prodigiosin with a broad range of cytotoxic activity $[16,17]$.

Janthinobacterium lividum. Anaerobic soil-dwelling, biofilm production bacterium with antibacterial, antiviral, antifungal, antioxidant, and anti-insect activity. Commonly isolated from the microbiota of soils and water of rivers, lakes, and springs, it was also found on certain amphibians' skin, including the red-backed salamander (Plethodoncinereus), where it prevents infection by the devastating chytrid fungus. J. lividum produces dark violet pigment - violacein and biosynthesis is regulated by aquorum - sensing system $[18,19]$.

Dinoflagellates. Classification subgroup of Protista, as common members of both the phytoplankton and the zooplankton of marine and freshwater ecosystems. They are also common in benthic environments and sea ice. Most dinoflagellates contain the pigments chlorophyll-a, chlorophyll-c, and carotenoids, and a group of xanthophylls that appears to be unique to dinoflagellates, typically peridinin, dinoxanthin, and diadinoxanthin. These pigments give many dinoflagellates their typical golden brown color. These organisms produce dinoflagellate luciferase, the main enzyme responsible for most of the bioluminescence observed in the surface ocean, and luciferin, a chlorophyll-derived tetrapyrrole ring that acts as the substrate to the light-producing reaction [20].

\subsection{Microbial component parameters}

The reflectance spectral signatures of selected microorganisms originate from the VPL (Virtual Planetary Laboratory) Biological Pigments database. Example reflectance plots in the $350-800 \mathrm{~nm}$ range are shown in fig. 2.

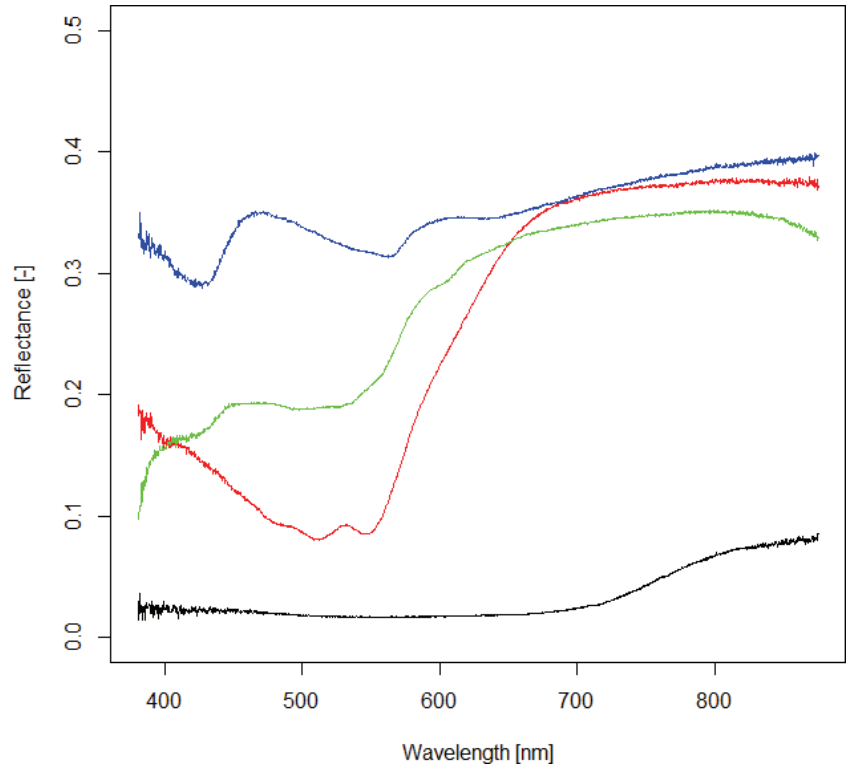

Fig. 2. Example microbial reflectance spectra in visible and near-infrared wavelengths: Brevibacterium aurantiacum (red), Deinoccocus radiodurans (green), Serratia marcescens (blue), and Janthinobacterium lividum (black)

Rys. 2. Przykładowe widma reflektancji mikroorganizmów w zakresie fal widzialnych i bliskiej podczerwieni: Brevibacterium aurantiacum (czerwony), Deinoccocus radiodurans (zielony), Serratia marcescens (niebieski) i Janthinobacterium lividum (czarny)

Physical parameters of particular cell s of selected microorganisms (mass, size) were obtained from the literature.

\subsection{Microbial component impact on the Enceladus' plume reflectance}

For the analyzed multispectral cameras, we consider the distance from the model plume in the range for which its height $(2000 \mathrm{~km})$ corresponds to a single pixel in the image. We also assumed that the main component of the plume's reflectance is Rayleigh scattering for 1-micrometre diameter ice crystals. The observed pixel brightness corresponding to Rayleigh scattering is disturbed by the influence of the biological component. We estimated this disturbance by calculating Rayleigh scattering for particles with the diameter of a selected microorganism, however, assuming that the molecule will absorb part of the electromagnetic radiation. We also assumed the particle density of the biological component at $10^{4}$ cells $/ \mathrm{cm}^{3}$.

Table 1. Physical parameters of selected microorganisms and examples of volatile organic compounds (VOC) produced by selected species Tabela 1. Parametry fizyczne wybranych mikroorganizmów i przykłady lotnych związków organicznych (LZO) wytwarzanych przez wybrane gatunki

\begin{tabular}{|c|c|c|c|c|c|c|}
\hline \multirow{2}{*}{ Sp. } & \multirow{2}{*}{ Cell size and dimension } & \multirow{2}{*}{$\begin{array}{l}\text { VOC assigned to } \\
\text { the microorganism }\end{array}$} & \multicolumn{4}{|c|}{ Mie scattering parameters for optical bands } \\
\hline & & & 0.4 (blue) & $1.0(\mathrm{NIR})$ & $5.0(\mathrm{IR})$ & $5.3($ IR) \\
\hline H. salinarum & $\begin{array}{l}\text { Oblong cell with a length of } \\
0.2 \mu \mathrm{m}[21]\end{array}$ & $\begin{array}{c}\text { 2-propylpentan-1-ol, Pentadecane, } \\
\text { Hexadecane, Benzaldehyde, } \\
\text { 1-Octen-3-ol [22] }\end{array}$ & 1.6 & 0.6 & 0.1 & 0.1 \\
\hline D. radiodurans & $\begin{array}{l}\text { Spherical cell with diameter } \\
\qquad 1-2 \mu \mathrm{m}[23]\end{array}$ & - & $7.8-15.7$ & $3.1-6.3$ & $0.6-1.3$ & $0.6-1.2$ \\
\hline C. neoformans & $\begin{array}{l}\text { Small-sized basidiospores } \\
1.8-3.0 \mu \mathrm{m}[24]\end{array}$ & $\begin{array}{c}\text { Ethanol, Acetaldehyde, } \\
\text { Crotonaldehyde (2-butenal) [25] }\end{array}$ & $14.1-29.8$ & $5.7-11.9$ & $1.1-2.4$ & $1.1-2.3$ \\
\hline P. putida & $\begin{array}{l}\text { Oblong cell with a length of } \\
1.5-3.0 \mu \mathrm{m}[26]\end{array}$ & $\begin{array}{c}\text { Benzene, Styrene, Toluene, } \\
\text { Trichloroethane [27] }\end{array}$ & $11.8-23.5$ & $4.7-9.4$ & $0.9-1.9$ & $0.9-1.8$ \\
\hline S. marcescens & $\begin{array}{l}\text { Oblong cell with the length } \\
1.0-2.0 \mu \mathrm{m} \text { and width } 0.5 \mu \mathrm{m}[28]\end{array}$ & $\begin{array}{c}\text { Dimethyl trisulfide, } \\
\beta \text {-Phenylethanol, Benzylnitrile [29] }\end{array}$ & $7.8-15.7$ & $3.1-6.3$ & $0.6-1.3$ & $0.6-1.2$ \\
\hline J. lividium & $\begin{array}{c}\text { Elongated cell with the length } \\
\text { range } 3 \mu \mathrm{m} \text { and width } 0.5 \mu \mathrm{m}[30]\end{array}$ & $\begin{array}{c}\text { Indole-3-carboxaldehyde, violacein } \\
{[31]}\end{array}$ & $3.9-23.5$ & $1.6-9.4$ & $0.3-1.9$ & $0.3-1.8$ \\
\hline Dinoflagellates sp. & $\begin{array}{l}\text { Spherical or irregular } \\
\text { microorganism, } \\
20-50 \mu \mathrm{m}[32]\end{array}$ & Isoprene, Dimethyl Sulfide [33] & $157-392$ & $62.8-157$ & $12.6-31.4$ & $11.8-29.6$ \\
\hline
\end{tabular}


Table 2. Multispectral cameras and mass spectrometers proposed in five Enceladus missions proposals

Tabela 2. Kamery wielospektralne i spektrometry masowe w pięciu proponowanych misjach do Enceladusa

\begin{tabular}{|c|c|c|c|c|}
\hline Mission & Instrument & Type & Main goal/description & Spectral parameters \\
\hline $\begin{array}{l}\text { Enceladus Orbiter } \\
\qquad \text { (EO) }\end{array}$ & $\begin{array}{l}\text { Medium- angle } \\
\text { Camera (MAC) }\end{array}$ & $\begin{array}{l}\text { VIS+NIR } \\
\text { camera }\end{array}$ & $\begin{array}{l}\text { The EO MAC would primarily be used to image the } \\
\text { Enceladus surface and plumes. } \\
\text { It would also be used for optical navigation. }\end{array}$ & $\begin{array}{c}\text { Visible light and near-infrared } \\
4 \text { optical channels, } \\
3.12 \mathrm{kbps} \text { data rate, } \\
5.8^{\circ} \times 0.15^{\circ} \text { field of view } \\
\end{array}$ \\
\hline \multirow[t]{2}{*}{$\begin{array}{l}\text { Enceladus Life } \\
\text { Finder (ELF) }\end{array}$} & $\begin{array}{l}\text { Enceladus Icy Jet } \\
\text { Analyzer (ENIJA) }\end{array}$ & \multirow[t]{2}{*}{$\begin{array}{c}\text { Mass } \\
\text { spectrometer }\end{array}$} & $\begin{array}{l}\text { The instrument is based on the principle of impact } \\
\text { ionization and optimized for the analysis of high dust } \\
\text { fluxes and number densities as typically occur during } \\
\text { Enceladus plume crossings or in cometary comae. } \\
\text { Depending on the density of the dust environment, } \\
\text { the sensitive area of the impact target can be switched } \\
\text { between } 0.8 \mathrm{~cm}^{2} \text { and } 12,5 \mathrm{~cm}^{2} \text {, respectively [34]. }\end{array}$ & $\begin{array}{l}\text { Size range } 0.01-100 \mu \mathrm{m}[34] \\
\text { The mass resolution } \\
\quad>970 \mathrm{M} / \mathrm{dM}\end{array}$ \\
\hline & \begin{tabular}{|c|} 
Mass Spectrometer \\
for Planetary \\
Exploration \\
(MASPEX)
\end{tabular} & & $\begin{array}{l}\text { Mass spectrometer capable of high-resolution and high- } \\
\text { a sensitivity that allows the determination of a wide } \\
\text { variety of chemical compounds in complex mixtures. }\end{array}$ & $\begin{array}{l}\text { Mass range }>1000 \mathrm{amu} \\
\text { Dynamic range } 109 / \mathrm{s} .\end{array}$ \\
\hline $\begin{array}{c}\text { The Explorer of } \\
\text { Enceladus and Titan } \\
\left(\mathrm{E}^{2} \mathrm{~T}\right)\end{array}$ & $\begin{array}{c}\text { Ion and Neutral } \\
\text { Mass Spectrometer } \\
\text { (INMS) }\end{array}$ & $\begin{array}{c}\text { Mass } \\
\text { spectrometer }\end{array}$ & $\begin{array}{l}\text { The E2T INMS' heritage would be based on P-BACE } \\
\text { instrument [35], RTOF instrument of ROSINA on } \\
\text { Rosetta and the gas chromatograph - neutral gas mass } \\
\text { spectrometer prototype by the Russian Space Agency } \\
\text { [36]. Most recently, a similar instrument, the Neutral } \\
\text { Gas and Ion Mass spectrometer (NIM) instrument of } \\
\text { the Particle Environment Package (PEP) consortium is } \\
\text { developed for the JUICE mission of ESA. }\end{array}$ & $\begin{array}{l}\text { The maximum INMS time } \\
\text { resolution at Enceladus is } 0.1 \mathrm{~s} \\
\text { for recording a mass spectrum } \\
\text { (corresponding to a spatial } \\
\text { resolution of } 0.5 \mathrm{~km} \text { for an } \\
\mathrm{S} / \mathrm{C} \text { velocity of } 5 \mathrm{~km} / \mathrm{s} \text { ) to } \\
\text { resolve small-scale structure in } \\
\text { the plume. }\end{array}$ \\
\hline \multirow{3}{*}{$\begin{array}{l}\text { Testing the } \\
\text { Habitability of } \\
\text { Enceladus's Ocean } \\
\text { (THEO) }\end{array}$} & $\begin{array}{l}\text { Titan Imaging and } \\
\text { Geology, Enceladus } \\
\text { Reconnaissance } \\
\text { (TIGER) }\end{array}$ & NIR camera & $\begin{array}{l}\text { Near-infrared (NIR) camera designed to acquire } \\
\text { high-resolution images of Titan and Enceladus. }\end{array}$ & $\begin{array}{l}\text { Surface resolution } 30-100 \mathrm{~m} / \mathrm{px} \\
\text { in } 1.3,2.0 \text {, and } 5.0 \mu \mathrm{m} \text { and } \\
\text { Enceladus emissions at } 1 \mathrm{~m} / \mathrm{px} \\
\text { at two wavelengths, } \\
5.0 \text { and } 5.3 \mu \mathrm{m} .\end{array}$ \\
\hline & $\begin{array}{l}\text { Space-borne } \\
\text { Water Analysis } \\
\text { by Molecule } \\
\text { Pulverization } \\
\text { (SWAMP) }\end{array}$ & $\begin{array}{l}\text { Mass } \\
\text { spectrometer }\end{array}$ & $\begin{array}{l}\text { SWAMP would measure element and isotope ratios as } \\
\text { well as molecule abundances. SWAMP is modelled after } \\
\text { MASPEX proposed as a part of ELF. }\end{array}$ & $\begin{array}{l}\text { Extended mass range: } \\
1000 \mathrm{amu}, \text { mass resolution } \\
30000 \mathrm{M} / \mathrm{dM} \text {, } \\
\text { sensitivity } 1 \mathrm{ppt}\end{array}$ \\
\hline & $\begin{array}{l}\text { Dynamic Resolution } \\
\text { Imaging of the } \\
\text { Plumes and Surface } \\
\text { (DRIPS) }\end{array}$ & Camera & $\begin{array}{l}\text { Images of plumes with }<10 \mathrm{~m} / \mathrm{px} \text { spatial resolution. } \\
\text { DRIPS would collect data essential to determining the } \\
\text { plume ice-vapour ratio, constraining libration amplitudes, } \\
\text { and investigating the thermal history of the ice shell. By } \\
\text { imaging, the plumes at a high phase in the visible band } \\
\text { at an order of magnitude higher resolution than possible } \\
\text { with ISS, THEO would create a data set of radiance } \\
\text { images that would be converted to I/F maps. }\end{array}$ & Visible light \\
\hline
\end{tabular}

\section{Missions instrumentation review}

Mission concepts to the moons of Jupiter and Saturn became popular after the success of the Cassini mission. We analyzed a set of instruments - multispectral cameras and mass spectrometers - proposed for four missions: Enceladus Orbiter (NASA), Enceladus Life Finder (NASA), The Explorer of Enceladus and Titan (ESA in collaboration with NASA) and Testing the Habitability of Enceladus's Ocean (JPL, MissionX).

\subsection{Multispectral cameras}

\section{Medium-Angle Camera}

Medium-Angle Camera (MAC) would be used primarily for imaging Enceladus' exteriors and plumes to map surface geology and measure sources and variability of plumes. It would also be used for optical navigation. MAC would work in push-broom mode, displaying the planet's surface with stripes that can be connected to generate a global map of the Enceladus surface. MAC has a high sensitivity in three to four colour bands and allows high-resolution imaging of the tiger stripes area. MAC would be analogous to the New Horizons spectral spectrum [37].
Its instrument requirements was four optical bands: 400-550 nm (blue), 540-700 nm (red), 780-975 nm (NIR), and 860-910 nm $\left(\mathrm{CH}_{4}\right)$ ) also allowing panchromatic imagining in the range of 400-970 nm [38]. With the MAC field of view $5.8 \times 0.15$ degrees, it is worthy to note that using Saturn orbit insertion velocity $v=7.073 \mathrm{~km} / \mathrm{s}$ the time between the plume will cover 5.8 degrees field of view and plume pass is only $8.8 \mathrm{~s}$.

\section{Titan Imaging and Geology, Enceladus Reconnaissance}

Titan Imaging and Geology, Enceladus Reconnaissance (TIGER) is a near-infrared (NIR) camera designed for acquiring high-resolution images. TIGER would observe Enceladus emissions with resolution $1 \mathrm{~m} / \mathrm{px}$ at two wavelengths: $5.0 \mu \mathrm{m}$ and $5.3 \mu \mathrm{m}$. Images obtained by TIGER would enable us to characterize the kinematics of Enceladus jets and plumes. The TIGER bands are selected to match the Titan atmospheric transmission windows to allow direct observation of the ground with reflected sunlight and measure thermal emissions from Enceladus. $5.0 \mu \mathrm{m}$ images would be very sensitive to organic composition. At Enceladus, observations of $5.0 \mu \mathrm{m}$ and $5.3 \mu \mathrm{m}$ would measure the thermal emission of surfaces as cold as $130 \mathrm{~K}$ and provide surface tem- 
perature maps on Cassini-ISS image scales. A precision control mirror (FSM) and spacecraft compensation will be used to select and track areas of interest during the flight, allowing longer exposure and a better signal-to-noise ratio (SNR). If necessary, digital time delay integration (TDI) will also be used during the next approach when ground speed is highest. At the closest approach, the velocity concerning the Enceladus surface is $\sim 5 \mathrm{~km} / \mathrm{s}$ [39].

\section{Dynamic Resolution Imaging of the Plumes and Surface}

The Dynamic Resolution Imaging of Plumes and Surface (DRIPS) is the camera dedicated to both main assignments: science tasks and optical navigation. The design is based on the previous cameras produced by Malin Space Science Systems. The camera would be imagining plumes at the high phase in the visible band at an order of magnitude higher resolution than possible with Cassini's ISS. DRIPS would generate a data set of radiance pictures that would be transformed into I/F maps. DRIPS would be able of recognizing a plume many orders of magnitude less massive than observed by Cassini by increasing the integration time, optimizing the phase angle, and a large number of proposed observations. While observing at $30 \mathrm{~km}$, the camera would map the south polar region up to $50^{\circ} \mathrm{S}$ with $10 \mathrm{~m} / \mathrm{px}$ spatial resolution [40]. Proposed flyby velocity is $\sim 6 \mathrm{~km} / \mathrm{s}$ [39].

\subsection{Mass Spectrometers}

\section{MAss SPectrometer for Planetary EXploration/Europa}

The device was intended for the Enceladus Life Finder mission, but the original purpose was designed for the Europa Clipper mission and also for the comet missions PRIME and Proteus. The mass spectrometer has an extended range for heavy organic particles (> $1000 \mathrm{amu}$ ), increased resolution compared to Cassini spectrometers, high throughput (> 5000 samples/s), and sensitivity better than 1 ppt. It is designed to detect isotopes of methane, water, ammonia, carbon monoxide, molecular nitrogen, $\mathrm{CO}_{2}$, and organic compounds that bind $\mathrm{C}_{2}, \mathrm{C}_{3}$, and $\mathrm{C}_{4}$. It can also measure noble gases such as argon, krypton, xenon, and their isotopes [41].

\section{Enceladus Icy Jet Analyzer}

This mass spectrometer is designed to analyse molecules such as amino acids and all types that can potentially be derived from Enceladus' plumes. It was designed and proposed for two missions: Enceladus Life Finder (ELF), and the Explorer of Enceladus and Titan $\left(\mathrm{E}^{2} \mathrm{~T}\right)$. The construction and operation of the spectrometer are based on the principle of impact ionization, which allows analyzing ice particles with a size of $0.1 \mu \mathrm{m}$ at a velocity of $5 \mathrm{~km} / \mathrm{s}$ [42]. ENIJA record 50 spectra per second and is sensitive for $\mathrm{H}+, \mathrm{C}$, and $\mathrm{O}$ ions.

ENIJA records time-of-flight mass spectra in the range between 1-2000 $\mathrm{mm}$ [34]. It can measure the content of carbon isotopes on ice particles and determine the ratio of elements such as $\mathrm{C}, \mathrm{N}, \mathrm{O}, \mathrm{S}\left(\mathrm{NH}_{3} / \mathrm{N}_{2}, \mathrm{H}_{2}\right)$ with sensitivity up to $0.1 \mathrm{ppm}$. Based on the carbon isotope ratio, it is designed to measure the condensation of organic matter in ice particles. The spectrometer may be used for amino acid identification and the ratio of carbon isotopes in ice crystals as life signatures estimation. It can determine the ratio of plume phases volatile to constant, which will allow finding the causes of the formation of eruptions and distribution of plume in space. Its sensitivity will also allow studying the salt content and mineralogical composition in plumes.

\section{Ion and Neutral Mass Spectrometer}

The mass spectrometer using the quadrupole mass system was designed to study the composition of Saturn and Titan atmospheres and also to measure the positive ions of the icy moons. It was constructed for the Cassini-Huygens mission, and currently, this type of spectrometer is planned for the mission of Explorer of Enceladus and Titan $\left(\mathrm{E}^{2} \mathrm{~T}\right)$ which is to help answer the question: Are major volatiles in plume material primordial (as opposed to geochemical or biological) and if so, how were they delivered [38]. The spectrometer will determine the quantitative composition of noble gases in Enceladus plumes: Ar, He, Ne and $\mathrm{Xe}$, measure the isotope ratios: ${ }^{12} \mathrm{C} /{ }^{13} \mathrm{C}, \mathrm{D} / \mathrm{H},{ }^{14} \mathrm{~N} /{ }^{15} \mathrm{~N},{ }^{16} \mathrm{O} /{ }^{18} \mathrm{O}$ in the Enceladus plume and separate the mass characteristics based on mass spectra and connect them to pressure changes. Like the ENIJA spectrometer, it will enable the separation of a solid phase of water and volatile to examine the eruption mechanism and whether processes to occur inside the moon. Based on the $\mathrm{NH}_{3} / \mathrm{N}_{2}$ ratios, $\mathrm{H}_{2}$ content will identify oxidized organic substances in the plume [38].

\section{Space-borne Water Analyzes by Molecule Pulverization}

SWAMP is the spectrometer for the Testing the Habitability of Enceladus's Ocean (THEO) mission and is modelled on the MASPEX spectrometer. Similar to MASPEX, this instrument is characterized by extended mass range ( $>1000 \mathrm{amu})$, mass resolution $(>30,000 \mathrm{M} / \mathrm{dM})$, and sensitivity (1 ppt). It is dedicated to plume composition research, in particular, detecting salts, amino acids, and higher-order hydrocarbons. The quantitative content of $\mathrm{CO}_{2}, \mathrm{CO}, \mathrm{H}_{2} \mathrm{O}, \mathrm{CH}_{4}, \mathrm{~N}_{2}, \mathrm{NH}_{3}, \mathrm{OH}$ volatiles is to assess the temperature conditions inside the ocean, its $\mathrm{pH}$ and examine the chemical and physical conditions of the particle transport mechanism. $\mathrm{Na}, \mathrm{Cl}, \mathrm{K}, \mathrm{N}$ measurements in plumes will approximate ocean salinity and the content of noble gases and their ratios will determine hydrothermal activity. Examination of $\mathrm{C}$ isotopes will allow estimating the genesis of biotic/abiotic processes. The spectrometer is adapted to detect the abundance of biomarkers in plumes such as amino acids, lipid acids, and nucleic acids [40].

\section{Microbial component detectability}

Assuming the base concentration of microorganisms on the surface of the Enceladus ocean on the order of $10^{4}$ cells $/ \mathrm{cm}^{3}$ [43], we estimate from above the amount of the microbiological component share among the particles forming the geyser at 1:100,000,000. Assuming that the distribution of these particles in the geyser plume is indistinguishable from the propagation of ice crystals and water vapour particles, we should consider this biological component density for the entire geyser. Earlier studies and numerical simulations [3, 6, 45] show, however, that for particles $>1 \mu \mathrm{m}$, the density distribution of the biological component particles depends on the height above the Enceladus surface. The average height above the moon's surface drops to $10 \%$ of the plume for particles with a diameter of two micrometres. After reaching maximum altitude, these particles might fall back to the surface creating the "snowing microbes" phenomenon.

To estimate the mass spectrometer parameters expected for microbial component detection, we need to estimate the maximum satellite altitude over the surface of Enceladus and estimate the spectral range for which the detection of particles corresponding to microorganisms' dimensions will be possible. It will be required to calculate the influence of the microbial component presence on the observed reflectance to estimate the parameters of multispectral cameras. The effect of particles with different sizes than water vapour particles and ice crystals on Mie (also Rayleigh approximation) scattering and visible and NIR radiation absorption should be considered.

\subsection{Mass spectrometers}

The detection of the microorganisms by mass spectrometers is not possible. Particles in the order of $1 \mu \mathrm{m}$ have a molecular weight of $10^{9}-10^{10} \mathrm{amu}$. The only way to recognize their appearance is to study the presence of their metabolism produces - volatile organic compounds (VOC) - such as alcohols, aldehydes, hydrocarbons, aromatic hydrocarbons, carboxylic acids, 
or ketones. Figure 3 contains the molecular weights of some of them. For large particles (comparable or larger than the average size of water vapour particles and ice crystals particles, $>1 \mu \mathrm{m})$, we can expect their higher density at the base of the geyser plume. However, it should be assumed for VOC particles that they will be equally distributed throughout the whole plume (see kinetic simulation results for $6 \mathrm{~F}$ and $1 \mathrm{~F}$ particles in [44]). VOC's assigned to selected microorganisms (Table 1) in opposition to the microorganisms themselves might be successfully detected using the spectrometers proposed. A comparison of the sample VOC's molecular weights with the spectral ranges of spectrometers is shown in figure3.

Three mass spectrometers sensitivity ranges: MASPEX, SWAMP, and INMS provide the detection of selected organic volatile compounds. Only the ENIJA spectrometer (ELF mission) can identify only lighter VOCs such as isoprene, benzene, or e.g. ethanol. However, these are often popular organic compounds assigned to the bacteria species. It should be noted that the mission Enceladus Life Finder is equipped with two spectrometers: ENIJA, which can be used to detect light compounds such as methane (16 amu) or carbon dioxide (44 amu) and MASPEX for heavier particles and MASPEX cover all of the selected VOCs.

While planning the orbit, the vertical differentiation of the density of microorganisms, especially the heavier ones such as C. neoformans, J. lividum, P. putida (up to $3 \mu \mathrm{m}$ ) or Dinoflagellates sp. (20-50 $\mathrm{mm}$ ) should not be taken into account. Direct detection of such heavy particles with the proposed spectrometers will be impossible. Only the detection of corresponding VOCs will be possible, while small particles such as VOCs, according to the results of numerical modelling of the spread of particles in Enceladus plumes [44], will spread uniformly throughout the plume volume. Therefore, the proposed for scientific orbits altitudes in the range of $50 \mathrm{~km}[34$, 39, 42] are accurate.

Another issue is the frequency of sampling by spectrometers. For velocity about $8 \mathrm{~km} / \mathrm{s}$ and a reference frequency of the MASPEX spectrometer about $5 \mathrm{kHz}$, we can estimate that one measurement carried out during the flight through the geyser plume will correspond to $1.6 \mathrm{~m}$ of the flight path. This is an excellent frequency that will allow recognizing the spatial distribution of VOC, and indirectly estimate the spatial distribution of microorganisms themselves.

\subsection{Multispectral cameras}

Investigating the parameters of multispectral cameras (MAC, TIGER, and DRIPS), we focused on the possibility of statistically significant differences in the spectrum between a geyser plume without microorganisms and a plume containing microorganisms. We assume that the main component of the spectral signature of the geyser reflectance is Mie or Rayleigh scattering depending on the size of the particles that form the plume and optical channel. Besides, this spectrum shape will be disturbed by the absorption of radiation by microorganisms.

Scattering is characterized by a dimensionless parameter

$$
x=2 \pi r / \lambda
$$

where $r$ is the radius of the scattering particle and $\lambda$ is the wavelength. For $x>>1$ particle will act as geometric shapes. We assumed that for $0.1<x<10.0$ we will use Mie scattering and for $\mathrm{x}$ in the range of $10^{\text {th }}$ we will use Rayleigh approximation.

In Table 1, there are listed microorganisms sizes and Mie scattering $x$ parameters for four wavelengths: $0.5 \mu \mathrm{m}, 1.0 \mu \mathrm{m}$, $5.0 \mu \mathrm{m}$, and $5.3 \mu \mathrm{m}$. These wavelengths represent minimum and maximum values for multispectral cameras MAC, TIGER, and DRIPS. In most cases, we can see that Mie scattering should be applied for both the visible - NIR spectrum and infrared spectrum used in the TIGER camera. Only for very small organisms $<0.5 \mu \mathrm{m}$, such as $H$. salinarum, in the case of the TIGER camera we can use the Rayleigh scattering model. For organisms with cells of the order of $3 \mu \mathrm{m}$ and larger in the case of short visible light wavelengths, e.g. in the blue and green channels, the cells will behave as geometric shapes. The same phenomenon will occur for the entire spectrum of all cameras for very large organisms like Dinoflagellates.

Mie (Rayleigh) scattering of a plume for incident sunlight power in the range of Saturnian orbit $14 \mathrm{~W} / \mathrm{m}^{2}$ containing ice crystals with a diameter of $1( \pm 0.5) \mu \mathrm{m}$ and composed of the microorganisms themselves listed in Table 1 are presented in fig. 4.

If we would replace ice particles with microbial component particles in a range a) 1:108 (uniform particles spreading) and b) 1:106 (higher density near plume source) and if we would apply calculated spectra to four visible/near-infrared optical bands proposed for Enceladus Orbiter MAC camera and for

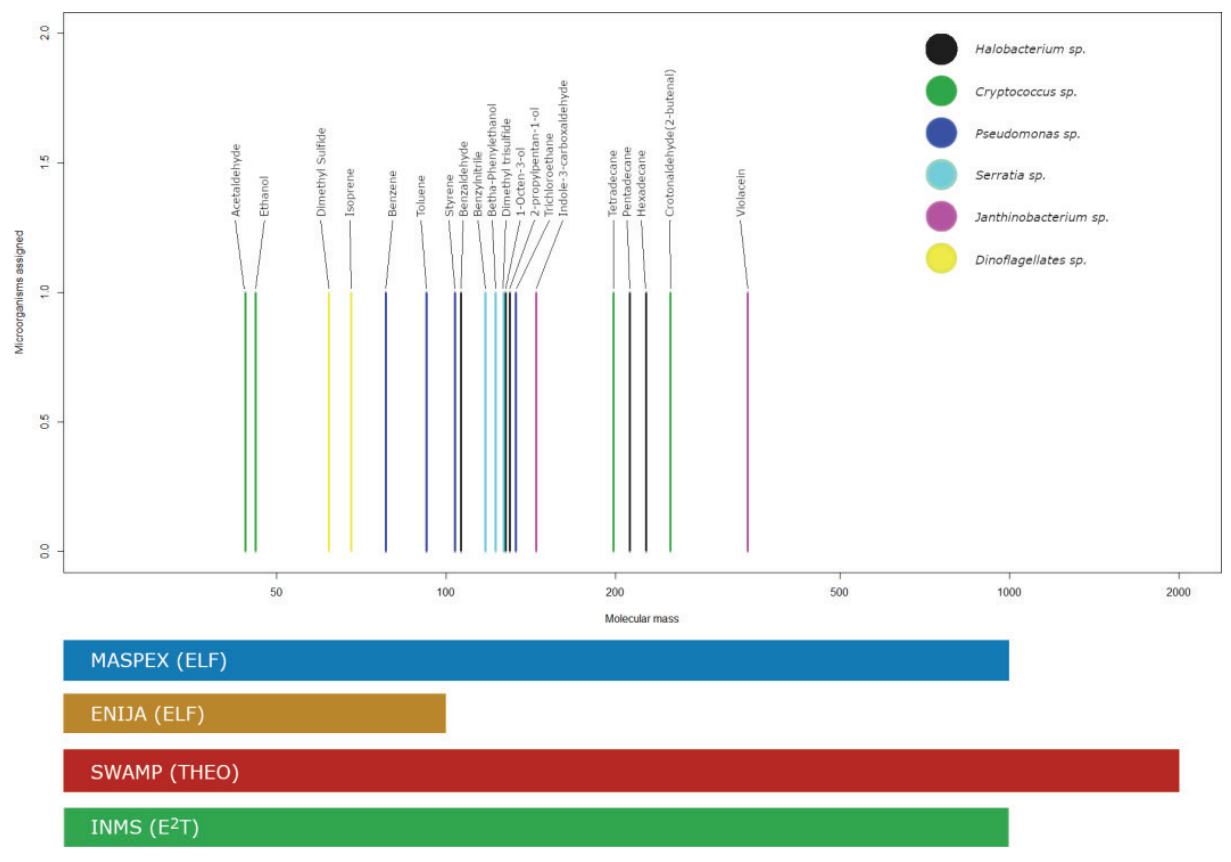

Fig. 3. Selected microorganisms VOCs, their molecular masses in the context of four mass spectrometers (MASPEX, ENIJA, SWAMP, and INMS) sensitivity Rys. 3. Lotne związki organiczne wybranych mikroorganizmów, ich masy cząsteczkowe w kontekście czułości czterech spektrometrów masowych (MASPEX, ENIJA, SWAMP i INMS) 
infrared band proposed for TIGER camera we may estimate reflectance relative change in all bands (see table 3 ).

Due to the dependence of Mie scattering on the dimension of the scattering particles and with a low density of the microbial component of $1: 108$, the observed changes in plume reflectance can be as low as 10,000 parts of a per cent. This is too little difference to be able to perform effective detection of microorganisms.

With 64-bit data storage for large microorganisms $(3 \mu \mathrm{m}$, e.g. C. neoformans, P. putida), the differences in the Digital Number (DN) in the visible and NIR range between the plume without the biological component and with the biological component would be as low as 200-500 (on a scale of 0 to about 4.5 billion). The situation is slightly better in the $5 \mu \mathrm{m}$ channel. The observed differences for organisms of the order of $2-3 \mu \mathrm{m}$ are about $2000 \mathrm{DN}$, for S.marscescens with a length of $2 \mu \mathrm{m}$ and a width of $0.5 \mu \mathrm{m}$ it is a difference of about $500 \mathrm{DN}$. These differences are in this channel, however, lower for very large objects such as Dinoflagellates. These differences are modified by the appearance of pigments in the biological component, which, as shown in fig. 2,

- cause light absorption at the level of $>60 \%$ in the entire visible and NIR spectrum, and

- differentiate the level of absorption in various bands.

For organisms such as $S$. marcescens and J. lividum, this differentiation is small $(<5 \%)$, but e.g. for B. aurantiacum or $D$. radiodurans these differences reach $20 \%$ and $10 \%$ respectively. It should be noted that the high light absorption for organisms larger than the average size of ice crystals in the plumes reduces the difference between the plumes without and with a microbiological component. For example, for J. lividium, a $60 \%$ absorption reduces this difference six times. For D. radiodurans in the NIR range or $\mathrm{NH}_{4}$ channel, this difference decreases fourfold, in the visible range de facto, falls to zero. Examining such properties with the differential indicators, we find that these variations are still too small (e.g. using NIR and Blue-Green channels, the differential indicator [NIR - Blue] /[NIR + Blue] would change by $10^{-6}$ ) to use such simple methods known for the detection of pigments, e.g. chlorophylls in cyanobacteria.

On the other hand, for microorganisms that are slightly smaller than $1 \mu \mathrm{m}$, the light absorption increases the reflectance variation. For significantly smaller organisms (e.g. H. salinarum $-0.2 \mu \mathrm{m})$ the main distinction is due to the difference in Mie scattering, and the light absorption itself is less important.

It can be assumed that the only opportunity to detect microorganisms in Enceladus plumes is their significant concentration around plume sources. Kinetic simulations [6] suggest that this could happen. If we assume that the same number of particles will spread at an altitude of up to $20 \mathrm{~km}$ instead of up to $2000 \mathrm{~km}$ causing the phenomenon of "snowing microbes" [34], then all these variations will become two orders of magnitude more significant. The density of microorganisms will increase due to their lower speed at the sources and the presence of cells returning to the surface. The differential ratio discussed earlier would increase for the source region from $10^{-6}$ to $10^{-3}$. It should be noted that assuming the main target of imaging the source of plumes, the camera parameters should be reconfigured
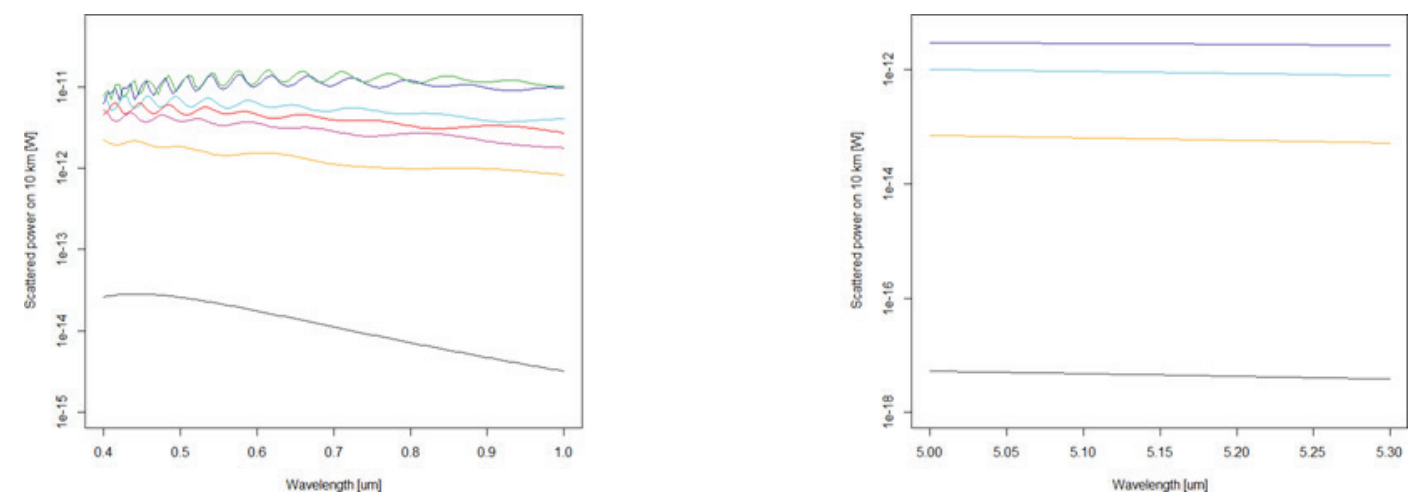

Fig. 4. Mie scattering (0.4-1.0 $\mu \mathrm{m}$, MAC and DRIPS cameras, 5.0-5.3 $\mu \mathrm{m}$ for TIGER camera) on the particle representing single-cell power flux observed on $10 \mathrm{~km}$ distance (1-2 s before passing plume) calculated for scattered angle $90-180$ degrees and basic sunlight flux 14 W/m ${ }^{2}$ (range of the Saturnian orbit). Colours as in Figure 3. Orange plot representing $1 \mu \mathrm{m}$ water particles.

Rys. 4. Rozpraszanie Mie (0,4-1,0 $\mu \mathrm{m}$, kamery MAC i DRIPS, 5,0-5,3 $\mu \mathrm{m}$ dla kamery TIGER) na cząstce reprezentującej pojedynczej komórki obserwowany na odległości $10 \mathrm{~km}$ (1-2 s przed przejściem przez pióropusz) obliczony dla kąta rozproszenia 90-180 stopni i strumienia padającego światła słonecznego $14 \mathrm{~W} / \mathrm{m}^{2}$ (odległość orbity Saturna). Kolory analogiczne do rys. 3. Pomarańczowy wykres przedstawia cząsteczki wody o średnicy 1 um.

Table 3. Change in plume reflectance after replacing ice crystals with particles of a biological component in a proportion of $1: 100,000,000$. The values in the table are expressed in thousandths of parts per mil

Tabela. 3. Zmiana współczynnika odbicia pióropusza po zastąpieniu kryształków lodu cząstkami składnika biologicznego w proporcji 1: 100000000. Wartości w tabeli są wyrażone w tysięcznych częściach na mil

\begin{tabular}{|c|c|c|c|c|c|}
\hline \multirow{2}{*}{} & \multicolumn{5}{|c|}{ Reflectance change due to the Mie scattering in the MAC \& TIGER cameras } \\
proposed bands [ppm]
\end{tabular}




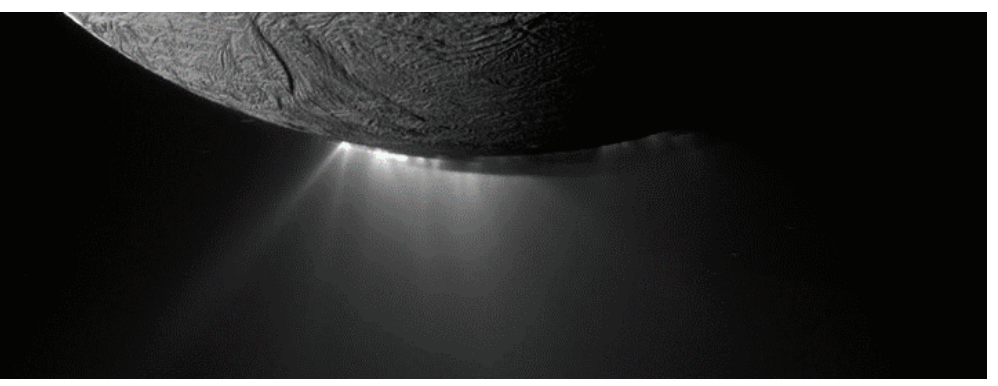

Fig. 5. Enceladus's south polar plumes, as seen by Cassini November 30,2010 . Plume's sources up to the $4000 \mathrm{~m}$ altitude are overexposed allowing higher parts of the plumes investigation [NASA/JPL-Caltech/ Space Science Institute]

Rys. 5. Pióropusze południowego bieguna Enceladusa, widziane przez sondę Cassini 30 listopada 2010 r. Źródła pióropusza na wysokości do $4000 \mathrm{~m}$ są prześwietlone, co pozwala jedynie na badanie wyższych części pióropusza [NASA / JPL-Caltech / Space Science Institute]

(e.g. lower exposure time) in such a way that the data for other regions of the plume (e.g. lower density regions in the higher altitudes) may be imaged with worse tonal resolution (fig. 5).

\section{Conclusions}

Designing optoelectronic systems for the detection of the microbiological component in Enceladus geysers is a complex process. First, it is necessary to estimate the parameters of the component, which is difficult because the actual parameters of the environmental conditions under the ice crust are unknown. Based on data from the Cassini probe, it is generally accepted that there is as an aline (1-2\%) ocean under the crust with a depth of $10 \mathrm{~km}$ to even $70 \mathrm{~km}$ and hydrothermal chimneys at its bottom that promote the creation and maintenance of microbiological life. The Cassini mass spectrometer indicated the presence of methane and molecular hydrogen in water plumes. This may indicate the presence of methanogenic archaealike organisms - similar to the hydrothermal field at the bottom of the Atlantic. However, the possibility of the existence of the microorganisms, extremophiles that tolerate high salinity, different temperatures, and X-rays from Saturn's rings or possibly from a heating source should not be excluded. In our work, we considered 7 different types of microorganisms. They are characterized by a large variety of sizes $(0.2-50 \mu \mathrm{m})$, some of them have varying reflectance spectra. Specific volatile organic compounds (VOCs) can be associated with specific microorganisms: from light compounds like ethanol to heavier ones like violaceins. Modelling of phenomena occurring in a hypothetical ocean and data collected on the hydrothermal field in the Atlantic indicate that on the ocean surface, at the place of geyser formation, the concentration of cells could be in the order of 10,000 per cubic centimetre, and at the source of the geyser 1 ppm concerning the micrometre size of ice crystals.

We estimated that it is impossible to detect the presence of microorganisms of the dimensions as mentioned above directly in geysers during designed missions using mass spectrometers. Their sensitivity allows for partial (e.g. ENIJA spectrometer in ELF mission) or full detection (MASPEX spectrometers from ELF mission and INMS from E2T mission) of corresponding volatile organic compounds in the range up to $2000 \mathrm{amu}$. The Enceladus Life Finder mission, which has two mass spectrometers: ENIJA for light particles such as ethanol, isoprene, or benzene, and MASPEX, which can determine e.g. violacein, can gather an extraordinary data set in this case. It is also important to emphasize the wide spectrum of the SWAMP device in the THEO mission. Since numerical models indicate that potential particles of this size should be present in the entire volume of the geyser and its plume, the proposed ceiling of the order of several dozen kilometres are suitable for collecting data. The proposed frequency of $5 \mathrm{kHz}$ will also ensure an appropriate spatial resolution of several meters during the flight.

The configuration of multispectral cameras for the detection of these types of organisms is a radically different issue. Due to the relative convergence of a) ice crystals sizes in the geyser $(1 \mu \mathrm{m})$, b) sizes of microorganisms $(0.2-50 \mu \mathrm{m})$ and c) visible electromagnetic wavelength, NIR and infrared $(0.4-1.0 \mu \mathrm{m}, 5.0-5.3 \mu \mathrm{m})$ that the main factors differentiating the reflectance of geyser light without a biological component from a geyser with a biological component will be a) Mie scattering, b) light absorption by microorganisms. The conducted analysis indicates that noticeable changes in the case of at least 64-bit data recording can occur only for larger than $1 \mathrm{\mu m}$ organisms at the source of geysers. It is troublesome because for such particles with sizes of 1-3 $\mu \mathrm{m}$ Mie scattering causes an increase in geyser brightness; however, the simultaneous absorption of light (40-80\% depending on the organism and optical channel) causes a decrease in brightness. Brightness variations of $1000 \mathrm{DN}$ in selected optical channels were determined for individual organisms in the range of $3 \mu \mathrm{m}$ size. The analysis showed that data from other parts of the plume (with lower matter density) may not provide sufficient detection information. Particularly noteworthy are the channels belonging to the near-infrared in the MAC camera (NIR and CH4 channels) and the infrared channel in the TIGER camera (5.0-5-3 $\mu \mathrm{m})$.

\section{References}

1. Eigenbrode J., Gold R.E., McKay C.P., Hurford T., Davila A., Searching for Life in an Ocean World: The Enceladus Life Signatures and Habitability (ELSAH) mission concept, 2018.

2. Matson D.L., Castillo-Rogez J.C., Davies A.G., Johnson T.V., Enceladus: A hypothesis for bringing both heat and chemicals to the surface. "Icarus", Vol. 221, No. 1, 2012, 53-62, DOI: 10.1016/j.icarus.2012.05.031.

3. Kotlarz J.P., Zalewska N.E., Enceladus' Plumes Reflectance. Particle-in-Cell Model Parametric Study, Cryovolcanism in the Solar System Workshop, Vol. 2045, 2018.

4. Glein Ch.R., Baross J.A., Waite J.H. Jr. The pH of Enceladus' ocean, "Geochimica et Cosmochimica Acta", Vol. 162, 2015, 202-219, DOI: 10.1016/j.gca.2015.04.017.

5. Taubner R.-S., et al. Biological methane production under putative Enceladus-like conditions. "Nature communications", Vol. 9, No. 1, 2018, 1-11, DOI: 10.1038/s41467-018-02876-y.

6. Kotlarz J., Kubiak K.A., Zalewska N.E., Potential Biological Component of the Enceladus Environment. Kinetic Simulation for the $10 \mathrm{~km}$ Thick Ocean Model. LPI Contributions, 2168, 2019 .

7. Brazelton W.J., et al. Archaea and bacteria with surprising microdiversity show shifts in dominance over 1,000year time scales in hydrothermal chimneys. Proceedings of the National Academy of Sciences 107.4, 2010, 1612-1617, DOI: 10.1073/pnas.0905369107.

8. Brazelton W.J., et al. Methane- and sulfur-metabolizing microbial communities dominate the Lost City hydrothermal field ecosystem. "Applied and Environmental Microbiology", Vol. 72, No. 9, 2006, 6257-6270, DOI: 10.1128/AEM.00574-06.

9. Kallmeyer J., ed. Life at Vents and Seeps. Vol. 5. Walter de Gruyter GmbH \& Co KG, 2017.

10. Kiang N.Y., Biosignatures of Exoplanets. (2017).

11. Saito Takeshi, et al. Hydroxyl radical scavenging ability of bacterioruberin. "Radiation Physics and Chemistry", Vol. 50, No. 3, 1997, 267-269, DOI: 10.1016/S0969-806X(97)00036-4.

12. Lemee L., et al. Deinoxanthin: a new carotenoid isolated from Deinococcus radiodurans. "Tetrahedron", Vol. 53, No. 3, 1997, 919-926, DOI: 10.1016/S0040-4020(96)01036-8. 
13. Rocío G.-R., et al. Role of Cln1 during melanization of Cryptococcus neoformans. "Frontiers in Microbiology", 2015, DOI: 10.3389/fmicb.2015.00798.

14. Liu G.Y., Nizet V., Color me bad: microbial pigments as virulence factors. "Trends in Microbiology", Vol. 17, No. 9, 2009, 406-413,

DOI: 10.1016/j.tim.2009.06.006.

15. Meyer J.-M., Pyoverdines: pigments, siderophores and potential taxonomic markers of fluorescent Pseudomonas species. "Archives of Microbiology", Vol. 174, No. 3, 2000, 135-142, DOI: $10.1007 / \mathrm{s} 002030000188$.

16. Bennett J.W., Bentley R., Seeing red: the story of prodigiosin. "Advances in Applied Microbiology", Vol. 47, 2000, 1-32, DOI: $10.1016 / \mathrm{s} 0065-2164(00) 47000-0$.

17. Haddix P.L., Shanks R.M.Q. Prodigiosin pigment of Serratia marcescens is associated with increased biomass production. "Archives of Microbiology", Vol. 200, No. 7, 2018, 989-999, DOI: $10.1007 / \mathrm{s} 00203-018-1508-0$.

18. Schloss P.D., et al. Psychrotrophic strain of Janthinobacterium lividum from a cold Alaskan soil produces prodigiosin. "DNA and Cell Biology", Vol. 29, No. 9, 2010, 533-541, DOI: $10.1089 /$ dna.2010.1020.

19. Cortés-Osorio N., et al. Influence of Environmental Factors on the Production of Violacein Synthesized By Janthinobacterium lividum. "The International Journal Of Engineering and Science", Vol. 6, No. 12017, 76-83, DOI: $10.9790 / 1813-0601037683$.

20. Valiadi M., Iglesias-Rodriguez D., Understanding bioluminescence in dinoflagellates - how far have we come? "Microorganisms", Vol. 1, No. 1, 2013, 3-25, DOI: $10.3390 /$ microorganisms1010003.

21. Offner S., et al. Structural characteristics of halobacterial gas vesicles. "Microbiology", Vol. 144, No. 5, 1998, 1331-1342, DOI: 10.1099/00221287-144-5-1331.

22. Alfonzo A., et al. Effect of salt concentration and extremely halophilic archaea on the safety and quality characteristics of traditional salted anchovies. "Journal of Aquatic Food Product Technology", Vol. 26, No. 5, 2017, 620-637, DOI: $10.1080 / 10498850.2016 .1251521$.

23. Zahradka K., Deinococcus Radiodurans - a Radiation Resistant Bacterium. $7^{\text {th }}$ Symposium of the Croatian Radiation Protection Associetion, Opatija, Croatia 2008.

24. Karkowska-Kuleta J., Rapala-Kozik M., Kozik A., Fungi pathogenic to humans: Molecular bases of virulence of Candida albicans, Cryptococcus neoformans and Aspergillus fumigatus, "Acta Biochimica Polonica", Vol. 56, No. 2, 2009, 211-224.

25. Scotter J.M., et al. Real-time detection of common microbial volatile organic compounds from medically important fungi by Selected Ion Flow Tube-Mass Spectrometry (SIFT$-M S)$. "Journal of Microbiological Methods", Vol. 63, No. 2, 2005, 127-134, DOI: 10.1016/j.mimet.2005.02.022.

26. Nelson K.E., Weinel C., Paulsen I.T., et al. Complete genome sequence and comparative analysis of the metabolically versatile Pseudomonas putida KT2440. "Environmental Microbiology", Vol. 4, No. 12, 2002, 799-808, DOI: 10.1046/j.1462-2920.2002.00366.x.

27. Detchanamurthy S., Gostomski P.A., Biofiltration for treating VOCs: an overview. "Reviews in Environmental Science and Bio/Technology", Vol. 11, No. 3, 2012, 231-241, DOI: $10.1007 / \mathrm{s} 11157-012-9288-5$.

28. Lee A., et al. Use of Hydrogenophaga pseudoflava penetration to quantitatively assess the impact of filtration parameters for 0.2-micrometer-pore-size filters. "Applied and Environmental Microbiology", Vol. 76, No. 3, 2010, 695-700, DOI: 10.1128/AEM.01825-09.

29. Kai M., et al. Volatiles of bacterial antagonists inhibit mycelial growth of the plant pathogen Rhizoctonia solani.
"Archives of microbiology", Vol. 187, No. 5, 2007, 351-360, DOI: 10.1007/s00203-006-0199-0.

30. Valdes N., et al. Draft genome sequence of Janthinobacterium lividum strain MTR reveals its mechanism of capnophilic behavior. "Standards in Genomic Sciences", 2015, DOI: $10.1186 /$ s40793-015-0104-z.

31. Woodhams D.C., et al. Prodigiosin, violacein, and volatile organic compounds produced by widespread cutaneous bacteria of amphibians can inhibit two Batrachochytrium fungal pathogens. "Microbial Ecology", Vol. 75, No. 4, 2018, 1049-1062, DOI: 10.1007/s00248-017-1095-7.

32. Wall D., Dale B., Quaternary calcareous dinoflagellates (Calciodinellidae) and their natural affinities. "Journal of Paleontology", Vol. 42, No. 6, 1968, 1395-1408.

33. Dani K.G.S., Loreto F., Trade-off between dimethyl sulfide and isoprene emissions from marine phytoplankton, "Trends in Plant Science", Vol. 22, No. 5, 2017, 361-372, DOI: 10.1016/j.tplants.2017.01.006.

34. Srama R., Postberg F., Henkel H., et al. Enceladus Icy Jet Analyzer (ENIJA): Search for life with a high resolution TOF-MS for in situ characterization of high dust density regions. Eur. Planet. Sci. Congr. 2015.

35. Abplanalp D., et al. A neutral gas mass spectrometer to measure the chemical composition of the stratosphere, "Advances in Space Research", Vol. 44, No. 7, 2009, 870-878, DOI: 10.1016/j.asr.2009.06.016.

36. Hofer L., et al. Prototype of the gas chromatograph-mass spectrometer to investigate volatile species in the lunar soil for the Luna-Resurs mission. "Planetary and Space Science", Vol. 111, 2015, 126-133,

DOI: $10.1016 /$ j.pss.2015.03.027.

37. Spencer J.R., Niebur C., Mission Concept Study: Titan Saturn System Mission. National Aeronautics and Space Administration, 2010.

38. Reuter D.C., et al. Ralph: A visible/infrared imager for the New Horizons Pluto/Kuiper Belt mission. "Space Science Reviews", Vol. 140, No. 1-4, 2008, 129-154,

DOI: $10.1007 / \mathrm{s} 11214-008-9375-7$.

39. Mitri G., Postberg F., Soderblom J.M., et al. Explorer of Enceladus and Titan (E2T): Investigating ocean worlds' evolution and habitability in the solar system. "Planetary and Space Science", Vol. 155, 2018, 73-90,

DOI: 10.1016/j.pss.2017.11.001.

40. Mackenzie S.M., Caswell T.E., Phillips-Lander C.M., et al. THEO concept mission: testing the habitability of Enceladus's Ocean. "Advances in Space Research", Vol. 58, No. 6, 2016, 1117-1137,

DOI: 10.1016/j.asr.2016.05.037.

41. Brockwell T.G., Meech K.J., Pickens K., et al. The mass spectrometer for planetary exploration (MASPEX). 2016 IEEE Aerospace Conference, DOI: 10.1109/AERO.2016.7500777.

42. Lunine J., Waite H., Postberg F., Spilker L., Clark K., Enceladus life finder: the search for life in a habitable moon. EGU General Assembly Conference Abstracts (2015)

43. Porco C.C., Dones L., Mitchell C., Could it be snowing microbes on Enceladus? Assessing conditions in its plume and implications for future missions, "Astrobiology", Vol. 17, No. 9, 2017, 876-901,

DOI: 10.1089 /ast.2017.1665.

44. Kotlarz J., Zielenkiewicz U., Zalewska N., Kubiak K., Microbial component detection in Enceladus snowing phenomenon; proposed missions instrumentation analysis. EANA Astrobiology Conference 2019. 


\section{Proponowane zadania aparatury misji na Enceladus w kontekście ich celów astrobiologicznych}

Streszczenie: Enceladus, księżyc Saturna, jest obiektem bardzo ważnym dla astrobiologów ze względu na obecność ciekłej wody, która tworzy ocean pokryty lodem. Gejzery lodu wodnego wydobywają się z regionu bieguna południowego przez pęknięcia w pokrywie lodowej. Sonda Cassini pobrała podczas lotu próbki pióropusza, rozpoznając, między innymi, metan i wodór cząsteczkowy. Od tamtej pory sformułowano hipotezy, że w pobliżu hydrotermalnych kominów Enceladusa mogą występować formy życia podobne do występujących w polu hydrotermalnym Lost City na dnie Atlantyku. W naszej pracy przeanalizowaliśmy możliwość wykrycia czynnika mikrobiologicznego w gejzerach Enceladusa. Posłużyliśmy się wybranymi ekstremofilami jako organizmami modelowymi. Przebadaliśmy kamery wielospektralne i spektrometry masowe przeznaczone do wykorzystania w proponowanych misjach do Enceladusa: Enceladus Orbiter, Enceladus Life Finder, The Explorer of Enceladus and Titan oraz misji THEO. Ich przegląd wykazał, że konfiguracja spektrometrów masowych oraz proponowane parametry orbit są odpowiednie do wykrywania lotnych związków organicznych odpowiadających wybranym mikroorganizmom, takich jak aldehyd, etanol, benzen, toluen, indol czy wiolaceina. Ewentualną obecność składnika mikrobiologicznego o wymiarach fizycznych rzędu kilku mikrometrów można zaobserwować jedynie dla obszarów formowania się gejzerów przy ich większej gęstości (> 10 ppm) oraz przy występowaniu zjawiska „snowing microbes”. Stwierdziliśmy, że szczególnie przydatne kanały optyczne to $780-975 \mathrm{~nm}, 860-910 \mathrm{~nm}$ oraz 5,0-5,3 $\mu \mathrm{m}$.

Słowa kluczowe: Enceladus, kamery wielospektralne, spektrometria mas, astrobiologia

\section{Katarzyna Kubiak, PhD}

Katarzyna.Kubiak@ilot.lukasiewicz.gov.pl ORCID: 0000-0002-4156-3139

She has graduated from the Warsaw University of Life Sciences. Since 2015 she has been working as an assistant professor at the Department of Remote Sensing, Łukasiewicz - Institute of Aviation and currently works with the acquisition and analysis of spectral data (laboratory and field spectrometry, UAV, satellites). The main research interests are the optimi sation of the configuration of optical sensors of multispectral cameras for imaging biomass and natural components.

\section{Natalia Zalewska, PhD}

natalia@cbk.waw.pl

ORCID: 0000-0001-8843-4396

She works at the Space Research Center of the Polish Academy of Sciences; she is a specialist in the field of Mars geological research conducted based on data from the Mars Express and MRO satellites. In 2005 and 2019, she took part in similar missions on this planet, organized by the Mars Society, which took place at the Martian base in the Utah desert. Currently, he is involved in the search for water and conical volcanoes on the surface of Mars. She is involved in the popularization of space through cooperation with the media.
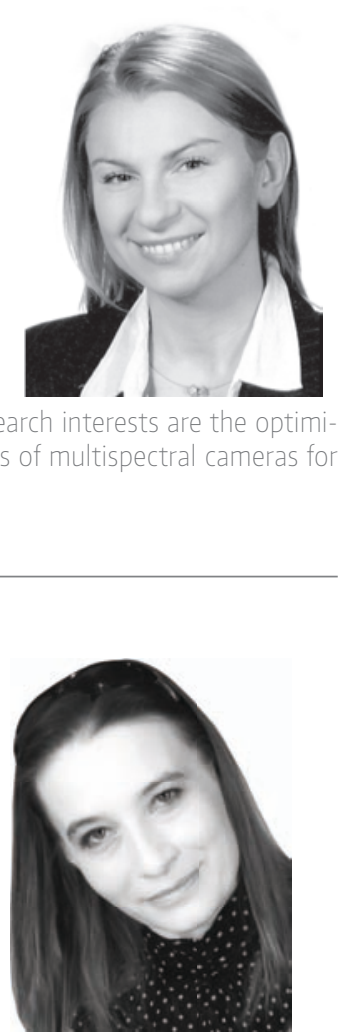

Urszula Zielenkiewicz, PhD

ulazet@ibb.waw.pl

ORCID: 0000-0003-0615-7546

She works at the Department of Microbial Biochemistry at the Institute of Biochemistry and Biophysics of the Polish Academy of Sciences, where she leads a group that researches the structure and microorganic biodiversity of biofilms that occur naturally in environments contaminated with arsenic compounds. 